\title{
Sक

\section{The Impact of CEFTA on Exports, Economic Growth and Development}

\author{
Victoria Pistikou ${ }^{1}$ \\ ${ }^{1}$ Assistant Professor, Department of Economics, Democritus University of Thrace, Greece
}

\begin{tabular}{l} 
ARTICLE INFO \\
\hline Article History \\
Received 28 September \\
2020; \\
Accepted 6 November 2020 \\
\hline JEL Classifications \\
F15, F50, F63
\end{tabular}
\begin{abstract}
Purpose:

The aim of the paper is to evaluate the impact of CEFTA on exports and economic growth and development of its members. Regionalism is attractive to states and especially to developing countries, since they enhance their reliability on reforms to foreign investors and they raise their bargaining power in multilateral level, since they negotiate as a unit and not individually, especially within the WTO, achieving goals which would not had been achieved if they had acted individually. The paper is based on the theoretical context of Regional Trade Agreements. More specifically, Free Trade Agreements widens trade in goods and services, raises exports and increases distribution of production. Moreover, FTAs affect state's reliability for inward investments, since they guarantee the implementation of domestic reforms. In particular, compared to WTO, within an FTA less countries are involved therefore, it is easier for them to monitor a state and if this state deviates from its commitments then it will face direct retaliation from other regional partners. Consequently, its members are considered more reliable and they experience a boost in economic growth and volume of trade.
\end{abstract}

Design/methodology/approach:

Methodologically it is based on analyzing quantitative macroeconomic data and qualitative data that have been quantified through a comparative analysis among members states. More specifically, the analytical framework consists of additional variables concerning economic and political freedom as well as trade volume, growth, development and income, since that all are correlated with trade liberalization.

\section{Findings:}

Keywords:

International Economic Relation, Regional Trade Agreements, Free Trade Agreements, CEFTA
In the case of CEFTA, intra-regional trade seems to be neglected since all CEFTA members prefer trading with the EU. This does not mean that CEFTA's economies could be more competitive than the $\mathrm{EU}$, however, there are is no increase in intra-regional trade volume and when there is, this concerns only few of the partners. In addition, indexes show that economic environment remains protected and state centric. The fact that an FTA such as CEFTA seems that does not have any impact on GDP growth but at the same time GDP per capita and HDI are increasing, might show that there are other variables which affect these indexes. another paradox is that these positive developments happen in highly corrupted, state-centric and protectionist members of a Free Trade Agreement.

Research limitations/implications:

FDI were not examined due to lack of data.

Originality/value:

Up to now, there are contradictory arguments in the literature regarding the effects of CEFTA on its members. More particularly, there are scholars who argue that CEFTA'S impact on exports and economic growth and development of its members is positive while others claim that this impact is either very limited or no existent at all. The current research aims to assess CEFTA's impact on growth and development taking into consideration the domestic economic and political environment. In addition, it extends recent work assessing CEFTA's effectiveness on member-states focusing on trade, economic growth and development by taking into consideration additional macroeconomic variables as well as the domestic capabilities of each member. 


\section{Introduction}

The aim of the study is to assess the impact of CEFTA on exports and economic growth and development of its members, extending the recent work taking into consideration the domestic economic and political environment. In 1947 advanced economies agreed in trade liberalization and tariff reduction, establishing the General Agreement on Trade and Tariffs, which was then turned into what we know today as the World Trade Organization. However, trade liberalization promoted both in global and regional lever. Great trading powers established Regional Trade Agreements (RTAs) in order to increase prosperity and create new markets for their products.

It is based on the theory of Regionalism, which creates the necessary conditions for deeper integration, bigger open markets and raises the flows of foreign direct investments. In particular, FTA's can increase foreign direct investments because of their impact on the cost of production. That is to say that maybe is more attractive for a company to take advantage of the labour cost within the regional market than before (Ravenhill, 2017). New Regionalism, on the other hand, results from competition for new markets. Due to trade diversion, many exporters push their government into joining an agreement (Baccini and Dür, 2012), therefore trade creation and trade diversion are important determinants in the formation of a FTA (Baier and Bergstrand, 2004).

Methodologically it is based on analyzing quantitative macroeconomic data and qualitative data that have been quantified through a comparative analysis among members states. More specifically, the analytical framework consists of additional variables concerning economic and political freedom as well as trade volume, growth, development and income, since that all are correlated with trade liberalization.

\section{Review of Literature}

\subsection{Theoretical Review}

The discourse on Regional Trade Agreements and Free Trade Agreements (FTA) in particular, is focused on the formation of FTAs as well as on their impact and implication on member's economies and trade liberalization. According to the theoretical aspects of regionalism, Regional Trade Agreements (RTA) are formed either for political or economic reasons (Ravenhill, 2017; Cooper and Massell, 1965; Cai, 2010; Gilpin 1981; Mastanduno, 1998; Higgot, 2004; Kelton 2008; Capling, 2008; Wesley, 2008; Hadjiyiannis et. al 2016). Baldwin's (1993, 1997) approach revealed that the domino effect caused by the major economic powers, such as the US, the EU and Canada is the main reason for the spread of regionalism while this was also a way to decrease discrimination effects caused by other FTAs (Baldwin and Jaimovich, 2012).

\subsection{Previous studies}

The impact of regional trade agreements on economic growth has been examined by scholars and most of them find insignificant effects (Hur and Park, 2012; Brada and Méndez, 1988; Vamvakidis, 1999; Jalles, 2012; Tumwebaze and Ijjo, 2015), while others found an increase in productivity and growth (Badinger and Breuss, 2011; Alcala and Ciccone, 2004; Karras, 2003; Liu, 2016). Regarding trade's openness, there are positive effects on growth (Dollar, 1992; Frankel and Romer, 1999; Dollar and Kraay, 2004; Freund and Bolaky, 2008; Atif et al. 2010; Kar et. al, 2008) while others argue that free trade's effects on growth are either insignificant or negative (Rodriguez and Rodrik, 2000; Wacziarg and Welch, 2008; Ramanayake and Lee, 2015). Nevertheless, there are more determinants which have been examined by scholars in order to assess to what extent regionalism, and FTA's in particular, can have a positive or negative impact on other economic components.

Regardless of the causes of FTA's formation, there are contradictory approaches about their impact on trade, especially when it comes to trade creation and trade diversion, which depends on the type of the agreement, meaning that deeper types of integration and the reduction of tariffs against non-member countries can lead to trade creation (Mattoo et al. 2017; Balassa, 1974; Richardson, 1993). More specifically, FTAs have substantial trade creation effects (Clausing, 2001; Krueger, 1999; Yang and Martinez-Zarzoso, 2014) however, sometimes cause intraregional trade diversion, especially in imports (Dai et al. 2014;)

However, trade creation can be fragile due to omitted variables that have not been taken into consideration (Ghosh and Yamarik, 2004; Baier and Bergstrand, 2007), especially when agricultural products are concerned, where tariffs remain in high levels and trade diversion is more likely (Sun and Reed, 2010; Ingco, 1995; Gibson et al. 2003; Sarker and Jayasinghe, 2007). In addition, trade diversion within a FTA is not noticeable due to growth of emerging market exports (Romalis, 2007) or due to foreign direct investments (Fukao et al. 2003).

Moreover, FTAs also increase bilateral and intra-regional trade volume (Anderson and Yotov, 2016; Baier and Bergstrand, 2007; Carrere, 2006) however, during the "New Regionalism" intra-trade volume was not significantly increased (Soloaga and Wintersb, 2001). In addition, regarding trade liberalization on poverty and income inequality, there are mixed results depending on country and region. More specifically, it is rather unclear whether gains from trade can alleviate poverty or income distribution since there are more variables that should be taken into account, such as trade policies or reforms (Borraz et al. 2012; Schejtman et al. 2009; Winters et al. 2004; Winters and Martuscelli, 2014) however, in some cases it is found that there is a positive effect between trade liberalization and income as well as reduction of income inequality (Ben-David, 1993; Cherkaoui et al. 2011; Porto, 2010; Nicita, 2009; Ariyasajjakorn, 2009). 
Mixed results occur as far as the impact of RTAs on foreign direct investments is concerned, depending on members and non-members as well as developed or developing economies. The correlation between FDI within a FTA is rather negative or unclear, since not all members within a RTA benefit the same (Jaumotte, 2004). More specifically, although FTA aim to promote economic activity either they decrease bilateral FDI or do not have significant impact on them (Jang, 2011; Reed et al. 2016; Kanazawa and Kang, 2019).

However, other scholars have noticed that in some cases, especially when there are liberal admission rules, regional integration is positively related to attracting FDI since there is a positive relationship between FDI and exports deriving from trade agreements, making creation effect more likely than diversion effect (Yeyati et al. 2003; Duong et al. 2019; Thangavelu and Narjoko, 2014; Li et al. 2016; Berger et al. 2013; Baltagi et al. 2008).

Summarizing, the existed literature, examines the impact of regionalism on member and non-member countries focusing more on economic growth, trade diversion and trade creation as well as FDI. Nevertheless, although there are mixed results, variables such as the economic freedom, developmental indexes with more macroeconomic indicators worth to be examined, since they may have an impact on FTA's effectiveness on economic growth and development of member-states creating a milestone which can lead to a greater integration and economic cooperation among regional partners.

In addition, more attention has been given to FTAs concerning great trade powers, such as NAFTA, MERCOSUR, or ASEAN, while little has been said for the Central European Free Trade Agreement (CEFTA) foe which there are also mixed results. More precisely, CEFTA, as a sub-regional integration programme, has benefited its member-states by expanding bilateral trade, especially exports, and their governments responded positively regarding trade liberalization policies, due to the EU pre-accession process (Dangerfield, 2004; Gjonbalaj et al. 2011; Petreski, 2013, 2018; Ćejvanović et al. 2014). However, according to other arguments, trade liberalization did not develop, due to political tensions among its members and if it wasn't for the pre-accession process of the EU, CEFTA's role would be eliminated (Begović, 2011; Milošević and Hrnjaz, 2018; Dangerfield, 2001).

The current research aims to assess CEFTA's impact on growth and development taking into consideration the domestic economic and political environment. In addition, it extends recent work assessing CEFTA's effectiveness on member-states focusing on trade, economic growth and development by taking into consideration additional macroeconomic variables as well as the domestic capabilities of each member.

\section{Methodology}

Regarding the methodology, in order to achieve the aim of the paper I will apply a quantitative method in a systematic comparison among member states of CEFTA. In the existed studies, most of the scholars focus on trade volume, trade liberalization and growth. This study also includes variables some of which have been examined in other RTA's but not in CEFTA, enriching the analytical framework for assessing CEFTA's impact on its members. More specifically, CEFTA's effect on income, development, foreign direct investments as well as economic growth should not be neglected.

\subsection{Measurement of Study Variables}

\subsubsection{Dependent Variable}

CEFTA's impact on exports, economic growth and development.

\subsubsection{Independent Variables}

The domestic political and economic environment is also taken into account due to correlation with trade liberalization policies for the following reasons. First, domestic political and economic environment and institutions are associated with trade negotiations, especially when it has to do with integration process (Milner and Rosendorff, 1996; Lohmann and O'halloran, 1994; Goldstein and Martin, 2000; Solís, 2010; da Conceição-Heldt, 2011; Langhelle, 2013; Langbein 2016; McKibben and Taylor, 2020; Madeira, 2016).

In particular, it is proved that trade liberalization is highly correlated with democracy and good governance since elections and democratization are negatively correlated with protectionism in trade agreements and reduces the government's likelihood to use trade barriers as a strategy and political freedom is correlated with economic freedom (Milner and Rosendorff, 1997; Milner and Kubota, 2005; Frye and Mansfield, 2004; Doces and Magee, 2015; Ramanzini Júnior and Luciano, 2020; Balding, 2011).

In addition, the correlation between political stability and trade liberalization in developing countries is based on domestic winners and losers due to redistributive effects of liberalization (Bussmann et al., 2006) and according to the theory of regionalism, "the opportunity that the negotiation of a free trade area provides companies to regionalize their production will be likely to worry labour unions in relatively high-wage countries that will fear that labourintensive stages of production will be moved to those parts of the region with lower labour costs." (Ravenhill, 2017:152). Additionally, Free Trade Agreements are more likely to be formed by unstable democracies since they reduce power from authoritarian groups (Liu and Ornelas, 2014). This is also reflected in international level where, according to scholars, RTAs reduce insecurity between states in conflict (Vicard, 2012; Martin et al., 2012).

Moreover, the correlation between rule of law and trade liberalization relies upon trust. More specifically, trade is positively correlated with trust between trade partners and increases when property rights are protected. Also, trust can be replaced by rule of law, when it operates well (Yu et al. 2015) and the quality of institutions as well as the institutional conditions are important factors which affect bilateral trade since they are positively correlated (Álvarez 
et al., 2018; Benacek et al., 2014; De Groot et al., 2004; Levchenko, 2007; Nunn and Trefler, 2014). In addition, there is the argument that Free Trade Agreements, such as CETA, do not protect democratic governance, undermine civil society and prioritize economic interests (Petersmann, 2015).

In addition, as far as corruption is concerned, it is clarified that it is correlated with democratization and liberalization process. In particular, corruption affects trade liberalization and trade policies since an open economy may increase corruption unless the liberalization is rapid, while protectionist measures increase corruption levels with negative impact on exports (Blackburn and Forgues-Puccio, 2010; Tavares, 2007; Bandyopadhyay and Roy, 2007; Lee and Azfar, 2008; Narayan and Bui, 2019). In addition, rapid trade liberalization does not eliminate corruption unless democratization happens simultaneously (Tavares, 2005) while levels of corruption are higher in countries with protectionist trade (Dutt, 2009).

Trade liberalization affects development, especially in developing countries. More specifically, it is used as a developmental strategy and it is associated with income and it is negatively associated with poverty, especially in developing countries, benefiting poor people (Siddiqui, 2015; Clairzier, 2011; Sudsawasd et al. 2020; Hamid and Amin, 2013; Jawaid and Waheed, 2017; Onakoya et al. 2019; Gnangnon, 2019).

Thus, these variables are related to qualitative characteristics, such as democracy, good governance, rule of law, development, corruption etc. which define state's capabilities in trade liberalization. Therefore, the analytical framework develops as follows: first, domestic determinants affected by CEFTA will be assessed and second, macroeconomic determinants, such as trade, FDI, development and economic growth will also be assessed, before and after the formation of CEFTA. A comparative analysis among its member-states will follow. The analytical framework is set out in Figure 1, below.

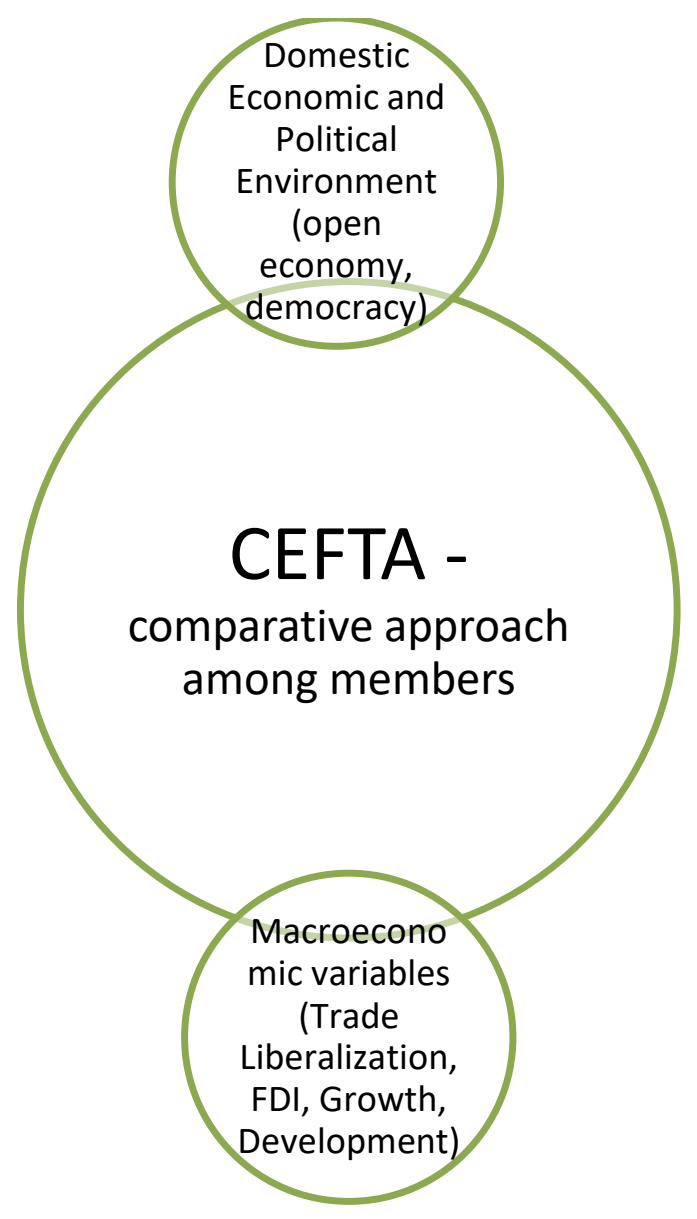

Figure 1. Analytical Framework 


\section{The Central European Free Trade Agreement - CEFTA}

According to the theory, RTAs are formed either for political or economic motives. The political motives of the creation of this FTA rely upon two pillars, that of security and cooperation and that of access to the European Union. Regarding the first pillar, the fall of the Berlin Wall and the end of the Cold War created rearrangements within the Balkan region. Since that time, states of the former USSR were in political and economic transition in order to create market economies and establish democratic governance based on the rule of law. However, this transition was not an easy process, due to conflicts and the raise of nationalistic aspiration, especially in areas of Yugoslavia and Croatia, Bosnia, Slovenia and Kosovo proclaimed their independence and sovereignty.

Under this unstable political environment, CEFTA came into force in 1992 in order to promote cooperation and economic growth among these states which was vital for their accession to the European common market. Given that some of its members, such as Poland, Check Republic, Romania, Bulgaria etc. joint the EU in the last two enlargements in 2004 and 2007, CEFTA form 2006 consists of seven states mainly of Western Balkans, such as Albania, Bosnia and Herzegovina, Moldova, North Macedonia, Montenegro, Serbia and the United Nations Interim Administration Mission in Kosovo on behalf of Kosovo in accordance with United Nations Security Council Resolution 1244 (WTO, 2020).

CEFTA's priorities reflect the challenges that member states need to address in order to achieve the necessary goals and respond to the E.U.'s conditionalities for their accession process. Despite the elimination of tariffs, there are still non-tariff measure among members states, such as "Excessive and redundant trade-related procedures, overlapping compulsory document and data submission requirements for companies, as well as excessive physical inspections at the borders are amongst them" making trade more expensive. Therefore, CEFTA's priorities are summarized as follows:

1. Horizontal support and private sector involvement

2. Harmonization of norms and practices for the elimination of non-tariff barriers

3. Standardization of document and data submission requirements

4. Simplification of customs clearance procedures (CEFTA, 2020(a))

In 2009, CEFTA along with the European Union and German Cooperation (GIZ) created the Open Regional Fund Foreign Trade which focuses on transparency issues in order to help members implement trade reforms and address market access barriers within the region. Statistics show that trade balance is negative either for extra or intra CEFTA trade.

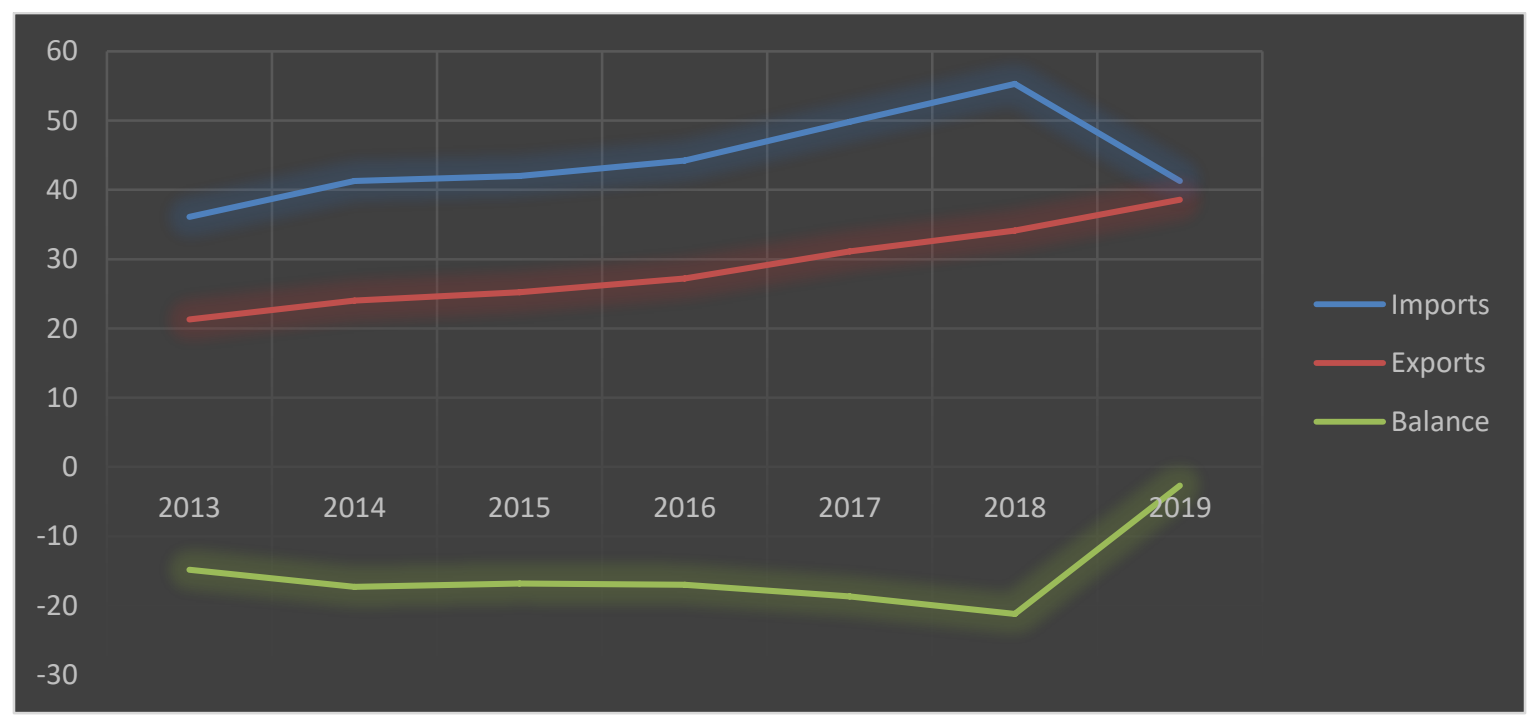

Source: CEFTA, 2020(b)

Figure 2. Extra-CEFTA trade in goods (in billion €)

More specifically, according to Figure 2, from 2013 to 2019 extra-CEFTA trade in goods had negative balance. Although exports increased by $80 \%$, imports also increased by $14 \%$ approximately. The trade balance tends to have positive prices only from 2019 onwards. On the other, hand intra-CEFTA trade in goods also had a positive balance, however, from 2018 there was in decline in exports. In particular, according to Figure 3, from 2015 to 2018 imports increased by $20 \%$ as well as exports by 30\%. However, from 2018 to 2019 imports continued raising in addition to exports which decreased from 5,6 to 3,1 billion $€$. 


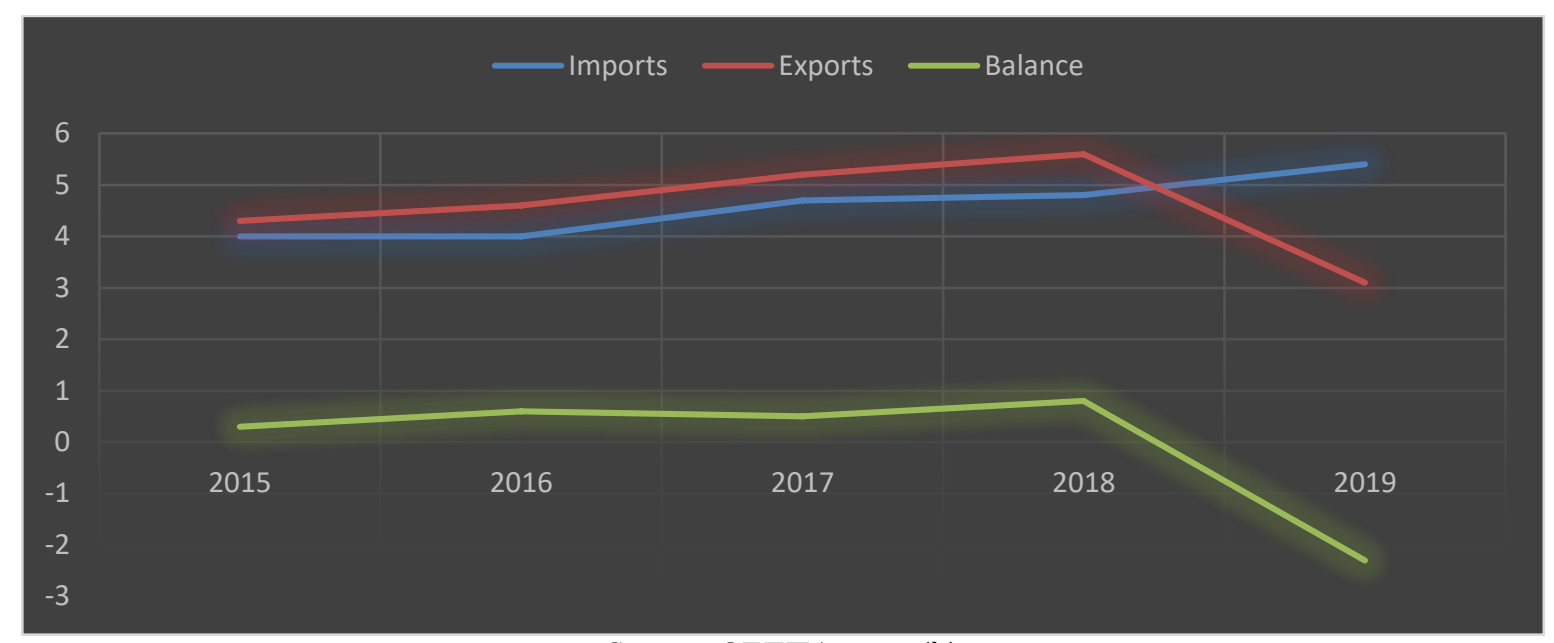

Source: CEFTA, 2020(b)

Figure 3. Intra-CEFTA trade in goods (in billion $€$ )

\subsection{Macroeconomic variables and Domestic Political and Economic Environment}

According to the 2020 Index of Economic Freedom, open markets concern Trade Freedom, Investment Freedom and Financial Freedom. Trade freedom measures the absence of tariffs and non-tariff barriers in imports and exports in goods and services. Non-tariff barriers include quantity restrictions, price restrictions, regulatory restrictions, investment restrictions, customs restrictions as well as direct government intervention. This index takes prices from 0 to 100 and the freedom scale is the following:

40-50: repressed

50-60: mostly unfree

60-70: moderately free

70-80: mostly free

$80+$ : free

Regarding trade freedom, CEFTA's members adopted trade liberalization policies in order to foster their production and their economic activity. More specifically, according to Figure 4, from 1995 to 2020 the score CEFTA's members raised between $78-88$, meaning that their trade was considered "mostly free".

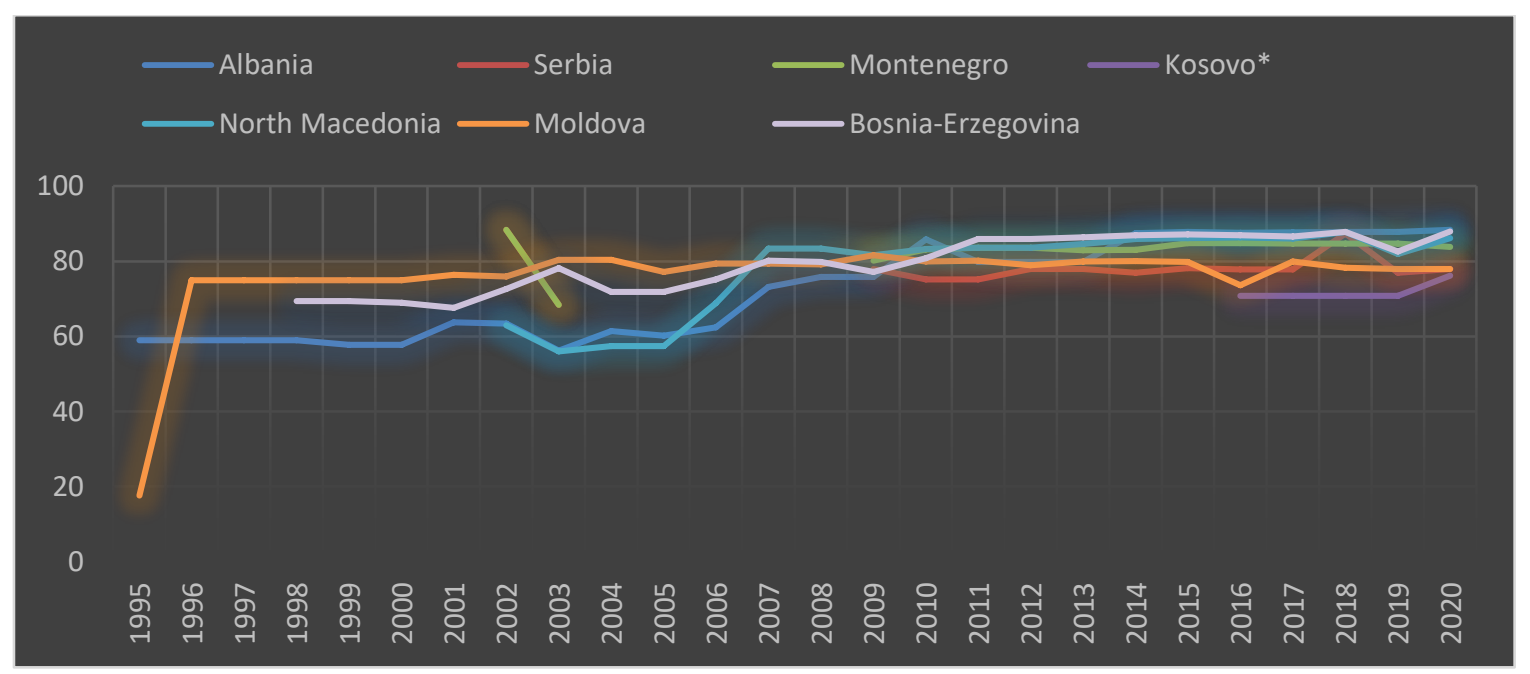

Source: Index of Economic Freedom, 2020

Figure 4. CEFTA’s Trade Freedom

On the contrary, from 1995 to 2009, Moldova, Albania and North Macedonia had the lowest prices, from 20 to 60. Thus, these countries had to overcome challenges caused by protectionist measures and follow policies related to trade liberalization.

Another significant indicator correlated to an open market economy is Investment Freedom, meaning that both individuals and firms can move their resources without restrictions. The current index takes prices from 0 to 100 according to restrictions, meaning that an ideal country without restrictions would receive a score of 100 . However, CEFTA's members impose restrictions even though there are some differences among them. 


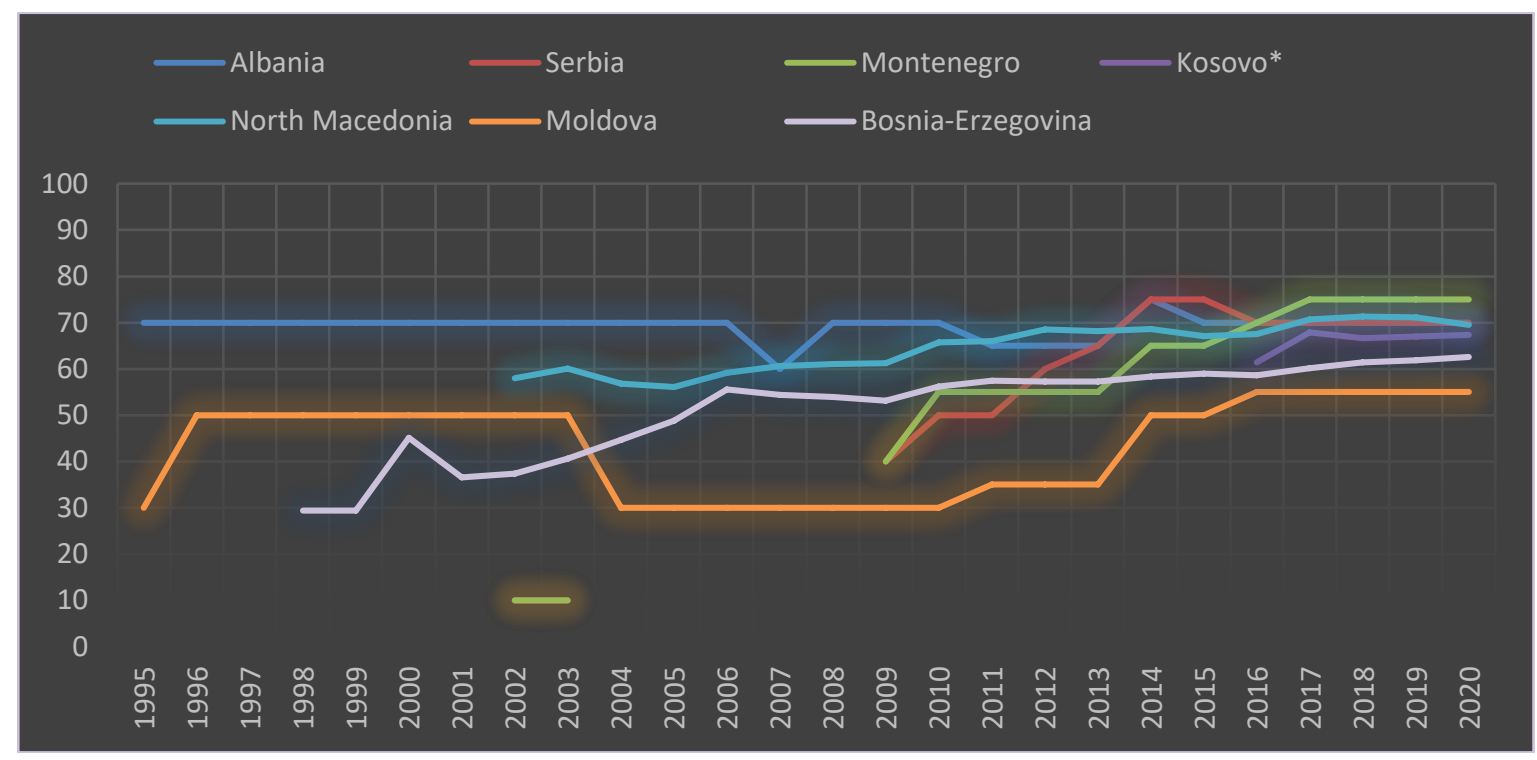

Source: Index of Economic Freedom, 2020

Figure 5. CEFTA's Investment Freedom

More specifically, according to Figure 5, from 1995 to 2020 most of the CEFTA members tried to reduce the restrictions in investments. Albania, Montenegro, North Macedonia and Serbia have the highest prices, from 70 to 75. However, other states such as Moldova remains in the lowest levels, that of 55, especially after a long period, from 2004 to 2010 which received a score of 30.

Financial freedom refers to the government intervention in the financial sector. Given that financial freedom increase competition providing financial services, financial transactions and credits are allocated on market terms without government intervention. The index takes into consideration the extent of government regulation of financial services, the degree of state intervention in banks and other financial firms through direct and indirect ownership, the extent of financial and capital market development, government influence on the allocation of credit, and openness to foreign competition. It takes prices from 0 to 100 where an ideal country without any government intervention would receive a score of 100 . The scale of government interference is set as follows:

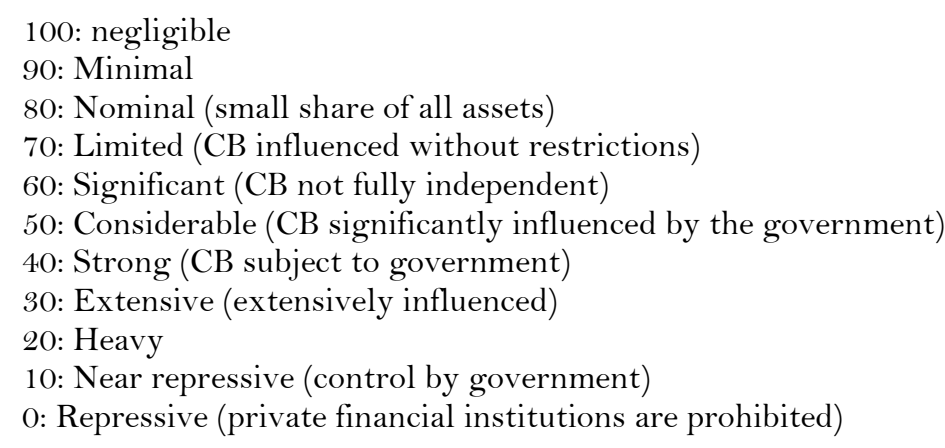

More specifically, as it is set out in Figure 6, CEFTA's members are below 70 meaning that government intervention in financial institutions and credit allocation is very high. 


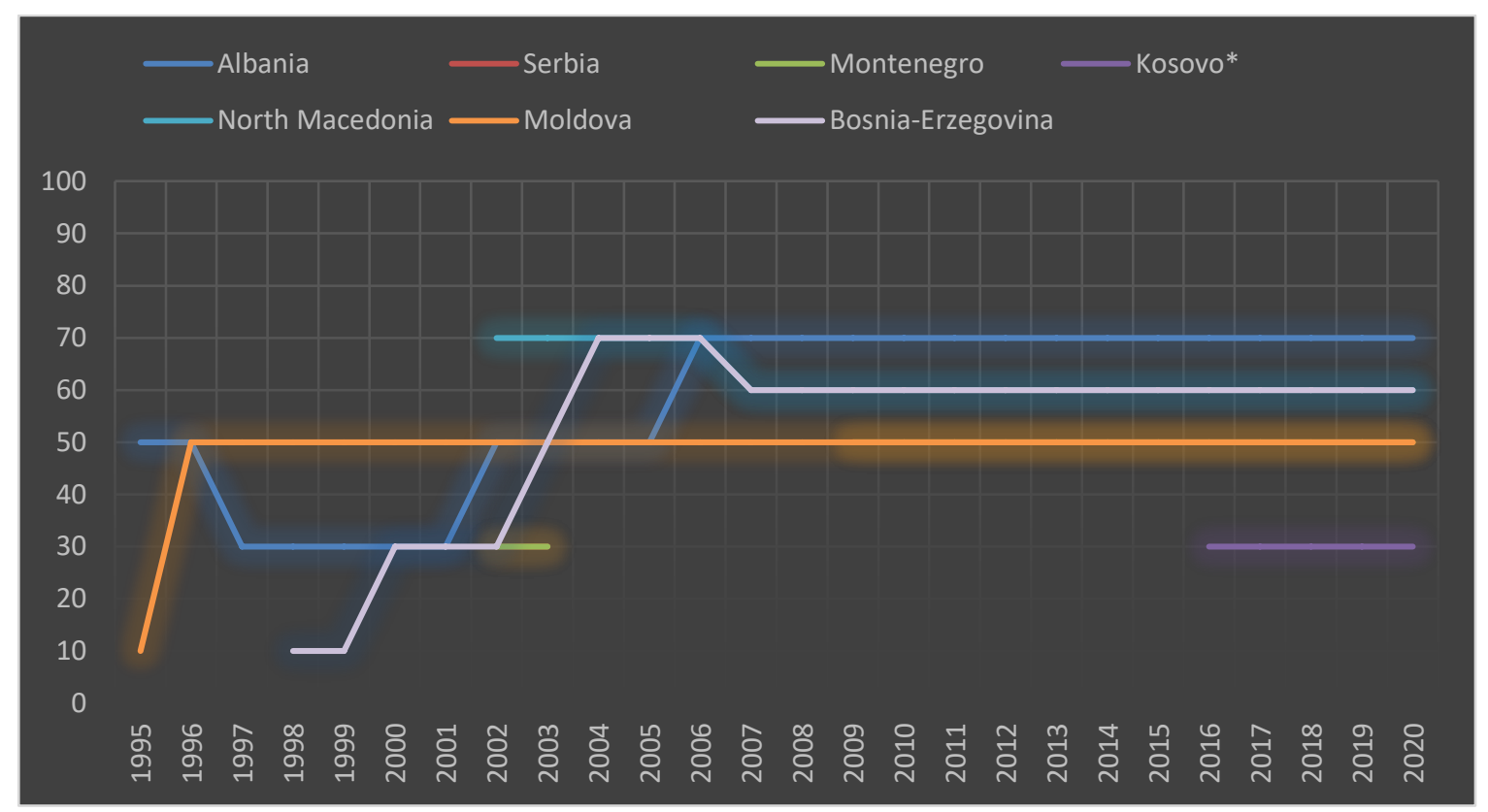

Source: Index of Economic Freedom, 2020

Figure 6. CEFTA’s Financial Freedom

In particular, from 2003 to 2020, banking sector is significantly influenced by government in Moldova, Kosovo*, Montenegro and Serbia in addition to more liberalized members such as Albania, North Macedonia and BosniaHerzegovina. Regarding the latter, is also noticeable that from 1998 where the score was 10 reached 70 in 2006 and finally 60 the rest of the years.

Another important element is the human development within CEFTA members. given that GDP per capita measures prosperity based only on quantitative data, the Human Development Index (HDI) takes into account qualitative determinants, such as years of schooling, life expectancy at birth as well as Gross National Income per capita (PPP). HDI aims to assess economic development not only economic growth, which is also affected by trade liberalization, since free trade, due to trade creation, gives people the opportunity to have access to many products responding to their needs and further develop their skills through specialization. HDI takes prices from o (low) to 1 (high).

According to Figure 7, HDI in CEFTA's members corresponds to that of developing countries. In particular, Montenegro, Serbia and Bosnia-Herzegovina are among the countries with the highest HDI, where Moldova has the lowest from 1990 to 2020. In addition, all members managed to increase their level during that period, especially Albania, which in 1990 its HDI was 0,64 and in 2020 is $0,79$.

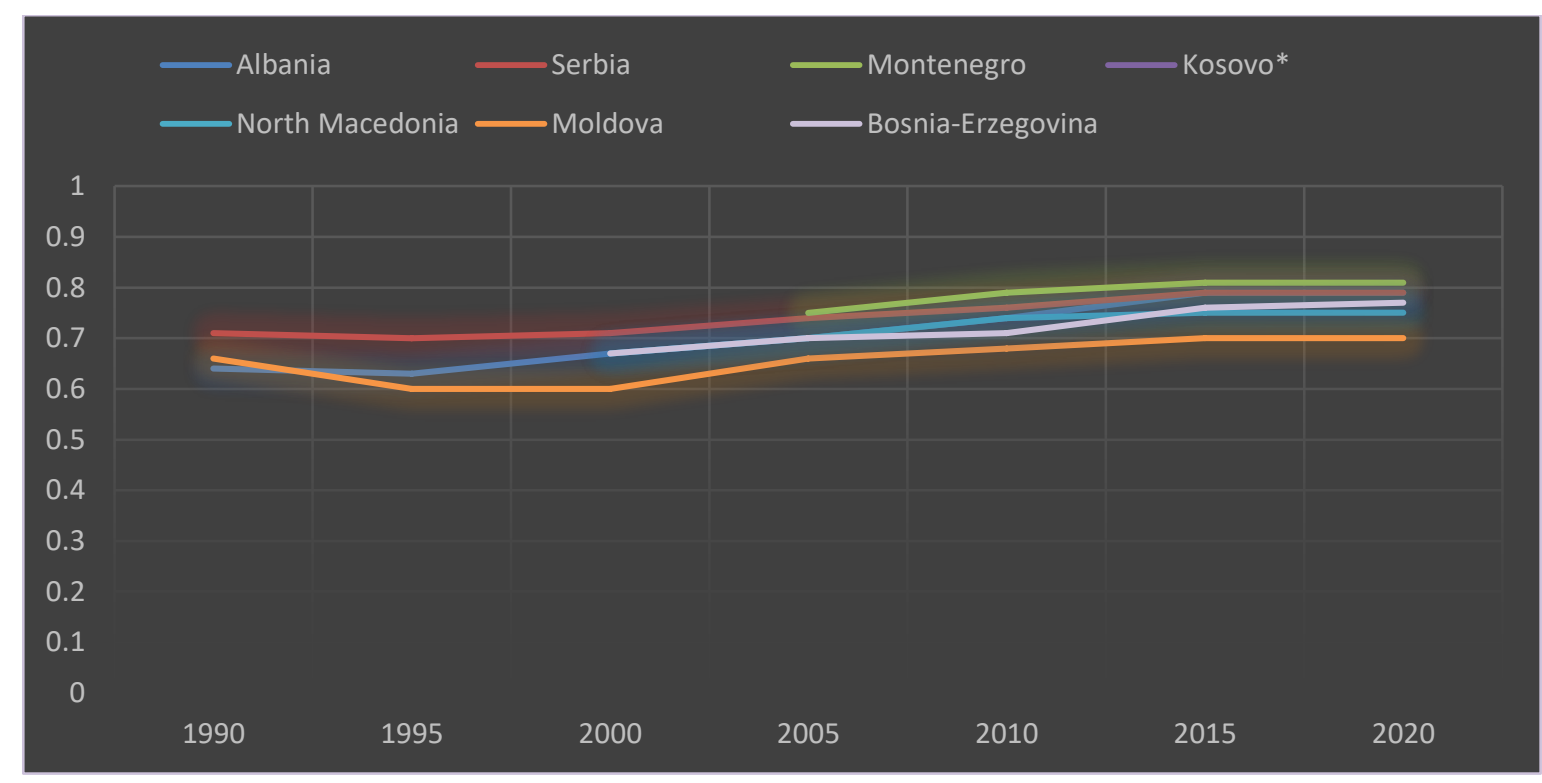

Source: HDI, 2020

Figure 7: CEFTA's Human Development Index 
Moreover, according to the literature, it is unclear whether trade is positively correlated with income inequality and alleviation of poverty. The below index, GINI coefficient, is implemented in CEFTA members and measures income inequality and takes prices from o (absolute equality) to 100 (absolute inequality). More specifically, according to Figure 8, the period between 2010 and 2017, income inequality was not so intense among CEFTA's members. North Macedonia has the highest price, that is 35,6 and Moldova the lowest, that is 25,9. This means that there are not any big imbalances regarding income distribution and inequalities among these members.

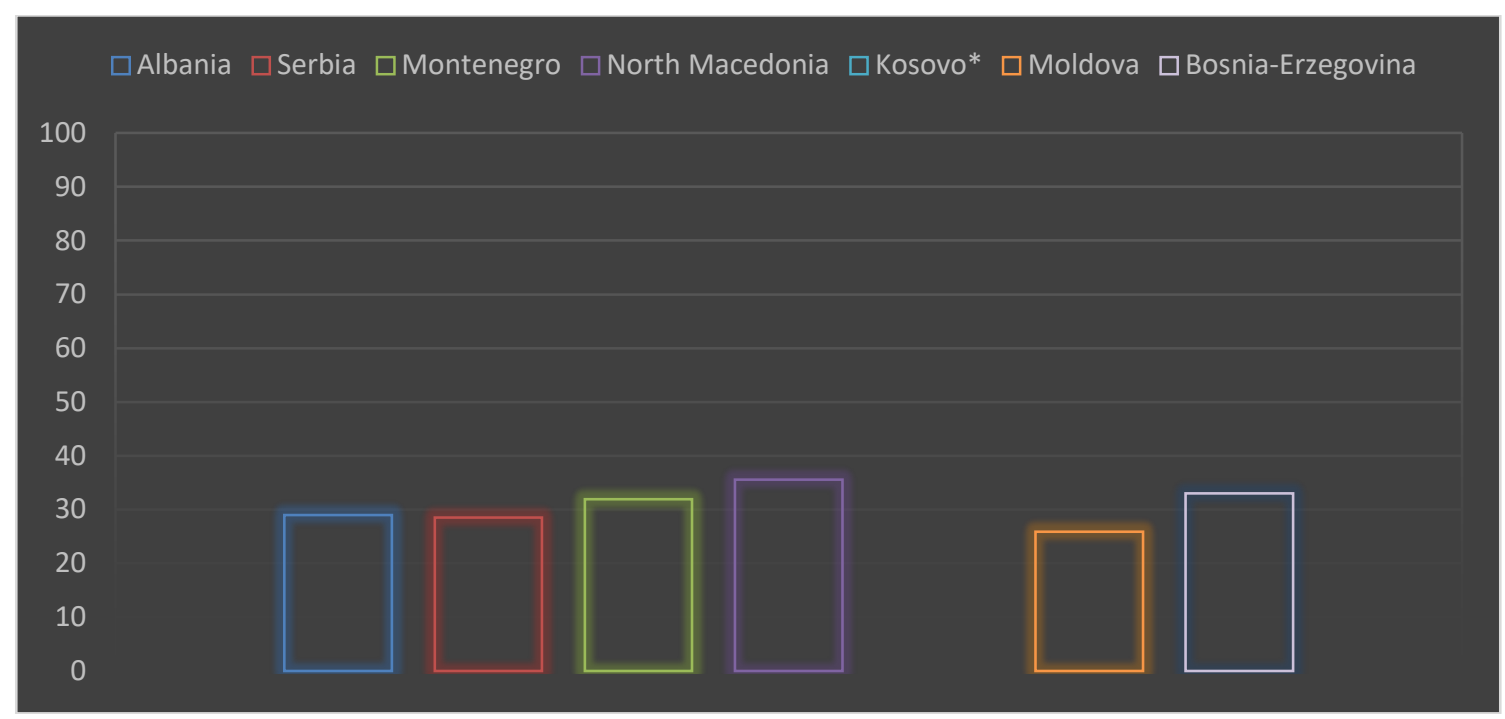

Source: UNDP, 2020

Figure 8: GINI Coefficient (2010-2017)

It is also interesting to assess the previous index (GINI) with GDP per capita among CEFTA's members. As it is set out in Figure 9, GDP per capita has an upward trend for all members. In particular, the increase in the prosperity of Montenegro is remarkable, since it has the highest GDP per capita in 2018, which is 21000 usd approximately. Serbia is in second place with 17000 USD and Moldova in last place with 12500 USD the same year.

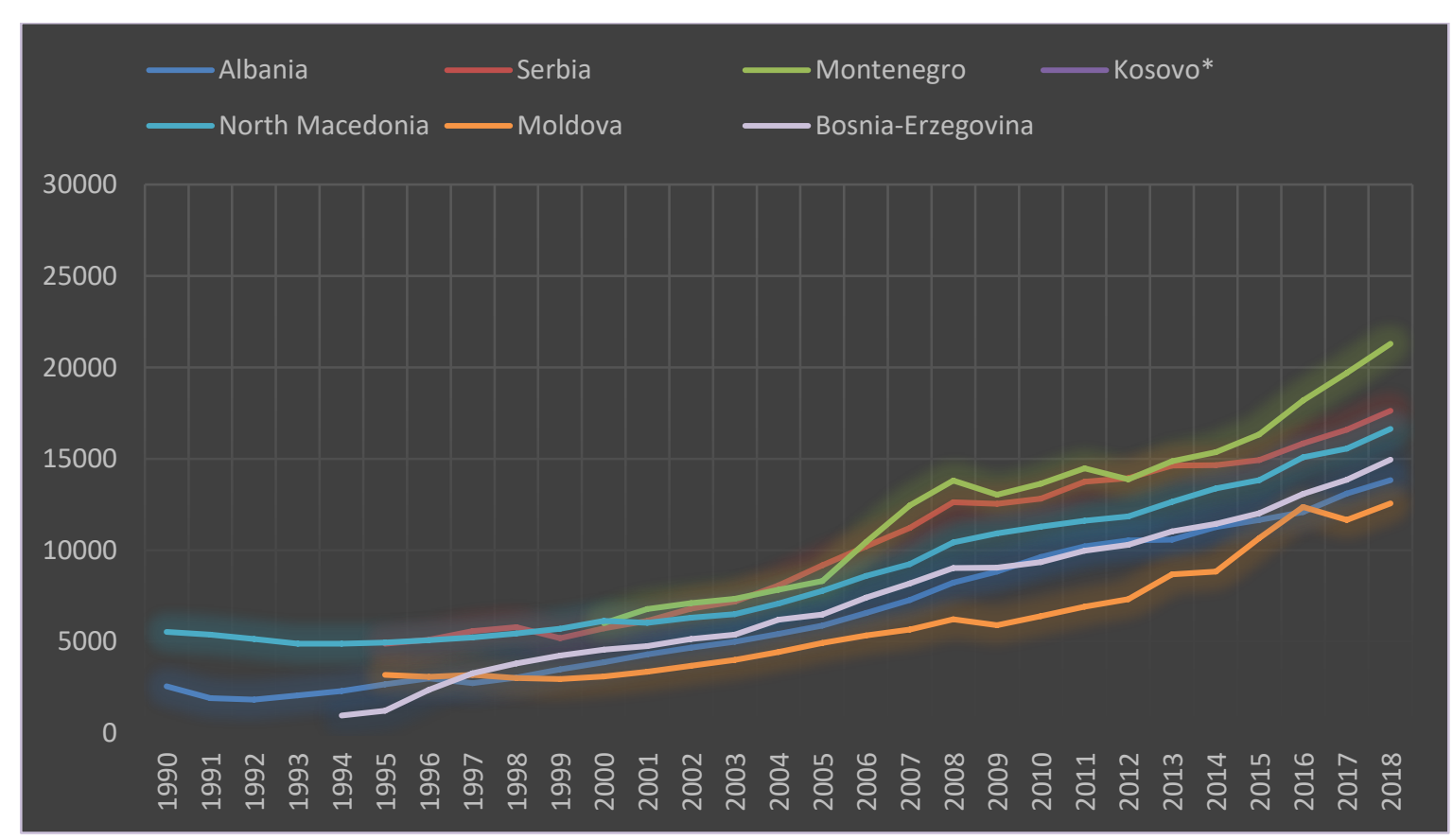

Source: World bank, 2020(b)

Figure 9: GDP per capita (PPP), USD

Trade is also positively correlated with GDP growth. According to Figure 10, CEFTA's economies before and after the formation of the FTA did not had significant changes. In particular, from 1990 to 1999 there were the lowest rates for Albania, North Macedonia, Serbia and Moldova, while during the same period, Bosnia and Herzegovina had 
the highest growth rate, $89 \%$ approximately. In 2009, due to financial crisis, there was also a slight decrease with negative rates apart from Albania and North Macedonia.

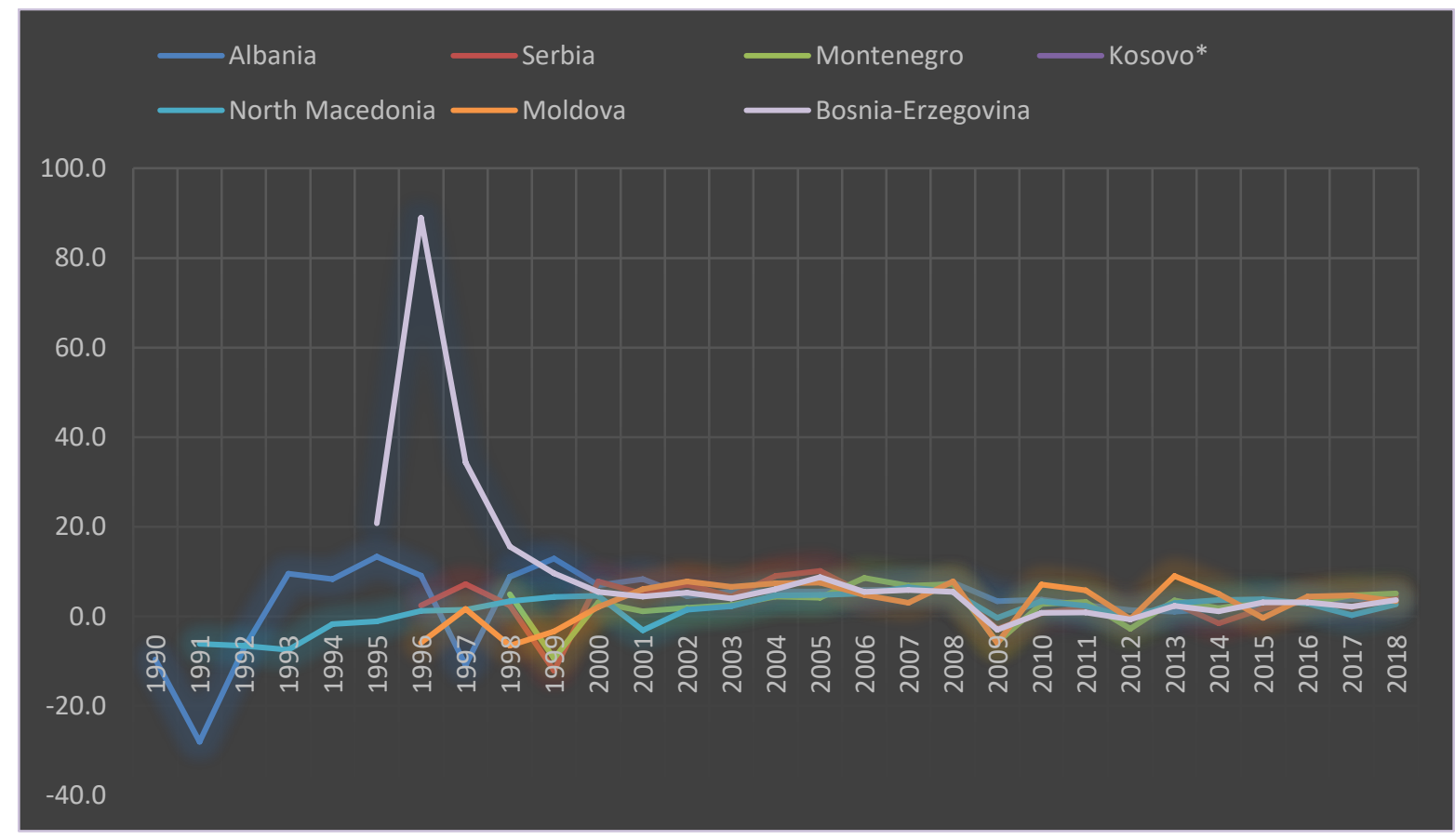

Source: World Bank, 2020(a)

Figure 10: GDP Growth (\%)

In addition, according to the literature, FTAs increase intra-reginal trade volume, therefore, it is important to focus on intra-regional trade. The absence of trading partners deriving from CEFTA in the case of Moldova is also noticeable, while North Macedonia and Albania, due to the to the opening of the accession negotiations, are more committed to the EU. As it is set out in Figure 11, the most significant export partner is the EU however, intraregional exports are very low as percentage of total exports. In particular, Albania's exports to Kosovo are only $8 \%$ of total exports while Bosnia-Herzegovina's exports to Serbia are only $9 \%$ of its total exports.

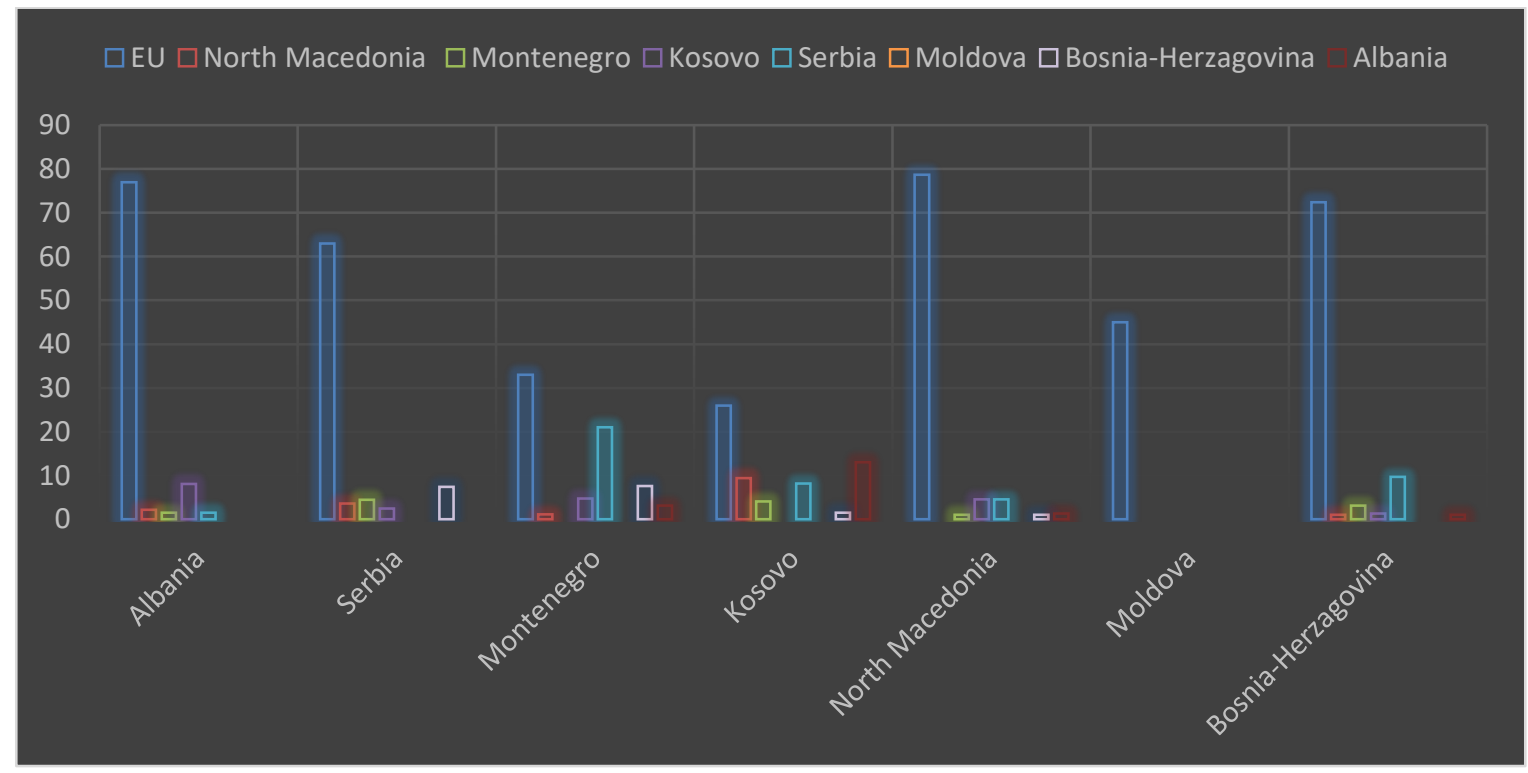

Source: CEFTA, 2020(b)

Figure 11: Export Partners (average, \% of total exports, 2013-2019)

With regard to import partners, there are similar results. According to Figure 12, the EU continue to be the most important import partner for CEFTA members while intra-regional imports correspond to very low rates of total imports. For example, Moldova's imports do not derive from CEFTA members while Serbia and Bosnia-Herzegovina import goods from two intra-regional partners, with these transactions corresponding to $3 \%$ and $10 \%$ of the total imports, respectively. 


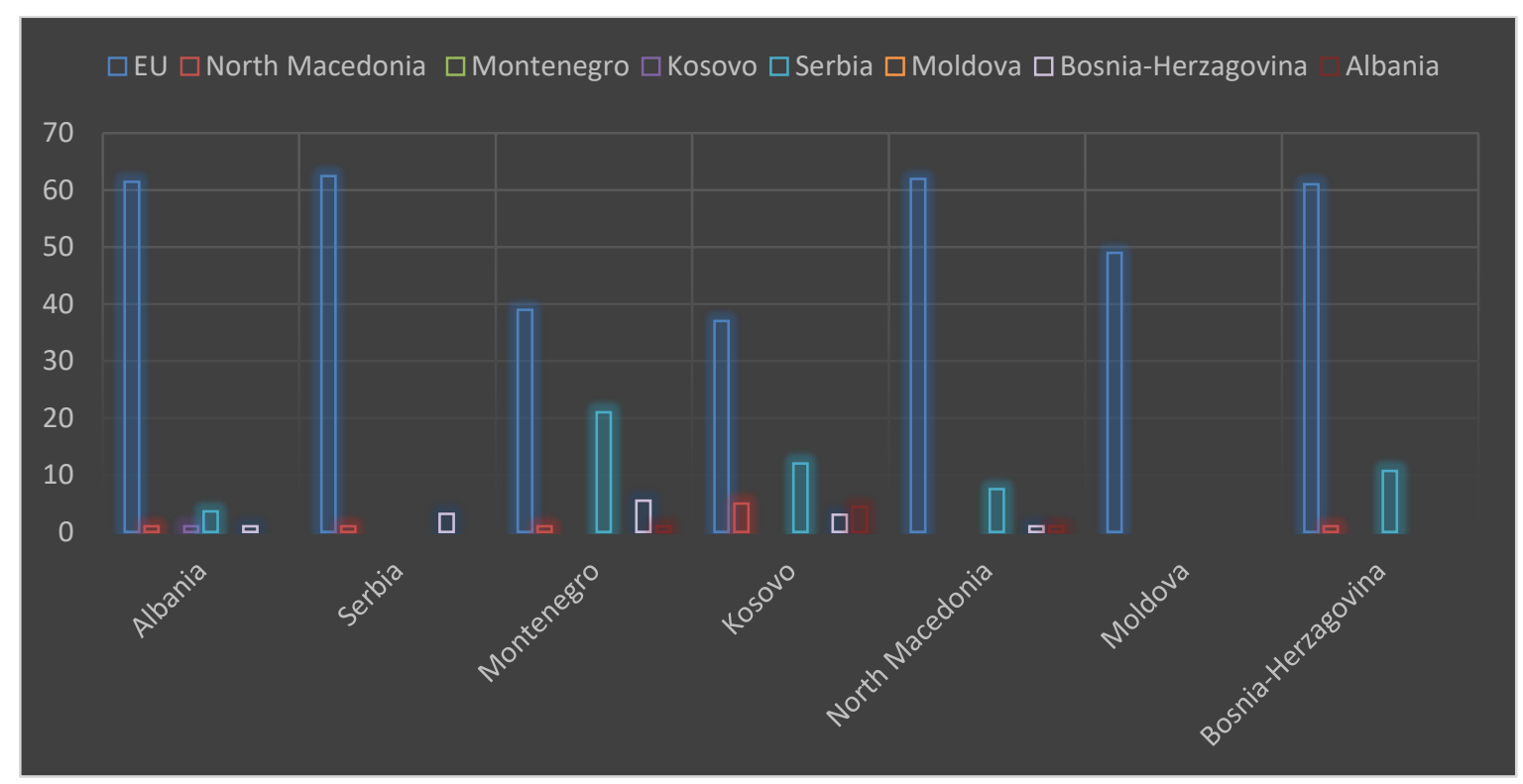

Source: CEFTA, 2020(b)

Figure 12: Import Partners (average, \% of total imports, 2013-2019)

Regarding the domestic political environment, according to the literature, it is critical to be stable and open in order to support an open market economy. Figure 13 shows to political stability and absence of violence for CEFTA members. This index takes prices from 0 to 100 , an ideal state would receive the score of 100. However, CEFTA members, are characterized by political instability and violence which also affects the economic aspect. In particular, Serbia, due to war in Kosovo, had the lowest score at o in 1998, however, from 2002 onwards managed to overcome the security challenges achieving one of the highest scores within CEFTA's region, that of 92. In addition, other members, such as Moldova, North Macedonia and Albania also had the lowest scores from 2004 to 2014, remaining at the same level of instability, which is not attractive for investments and further economic activity.

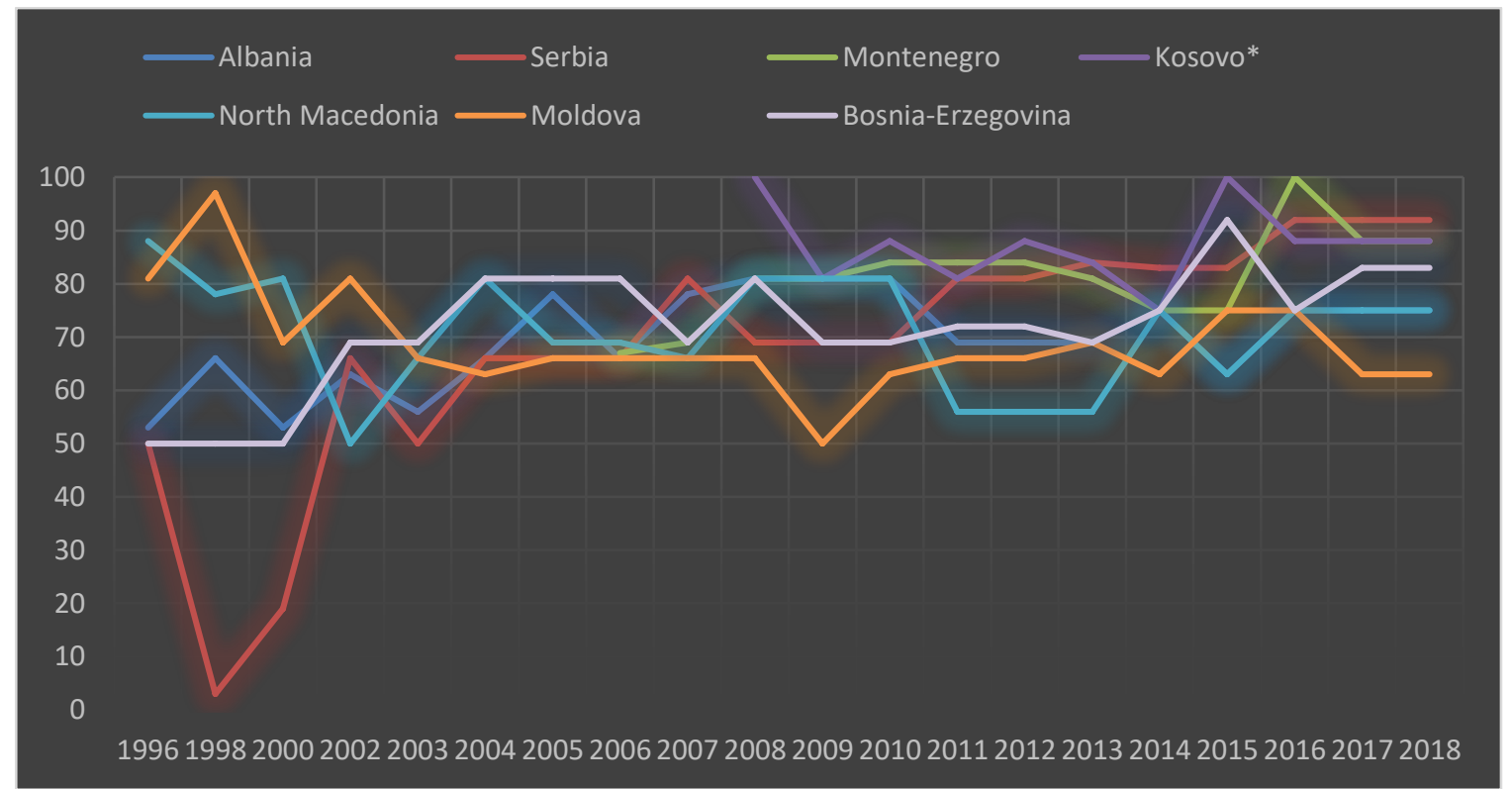

Source: WGI, 2020

Figure 13: Political Stability and absence of violence

Open political systems, such as Democracies, are also determined by the rule of law. According to this index, "Rule of law captures perceptions of the extent to which agents have confidence in and abide by the rules of society, and in particular the quality of contract enforcement, property rights, the police, and the courts, as well as the likelihood of crime and violence." (WGI, 2020). In particular, according to Figure 14, from 2002 to 2018 most of CEFTA's members raised their rates however they did not manage to score over 80. Albania has the lowest level, approximately 50 followed by Moldova and Kosovo* with 55. On the contrary, Montenegro and Serbia are in first and second place with 68 and 60 respectively. 


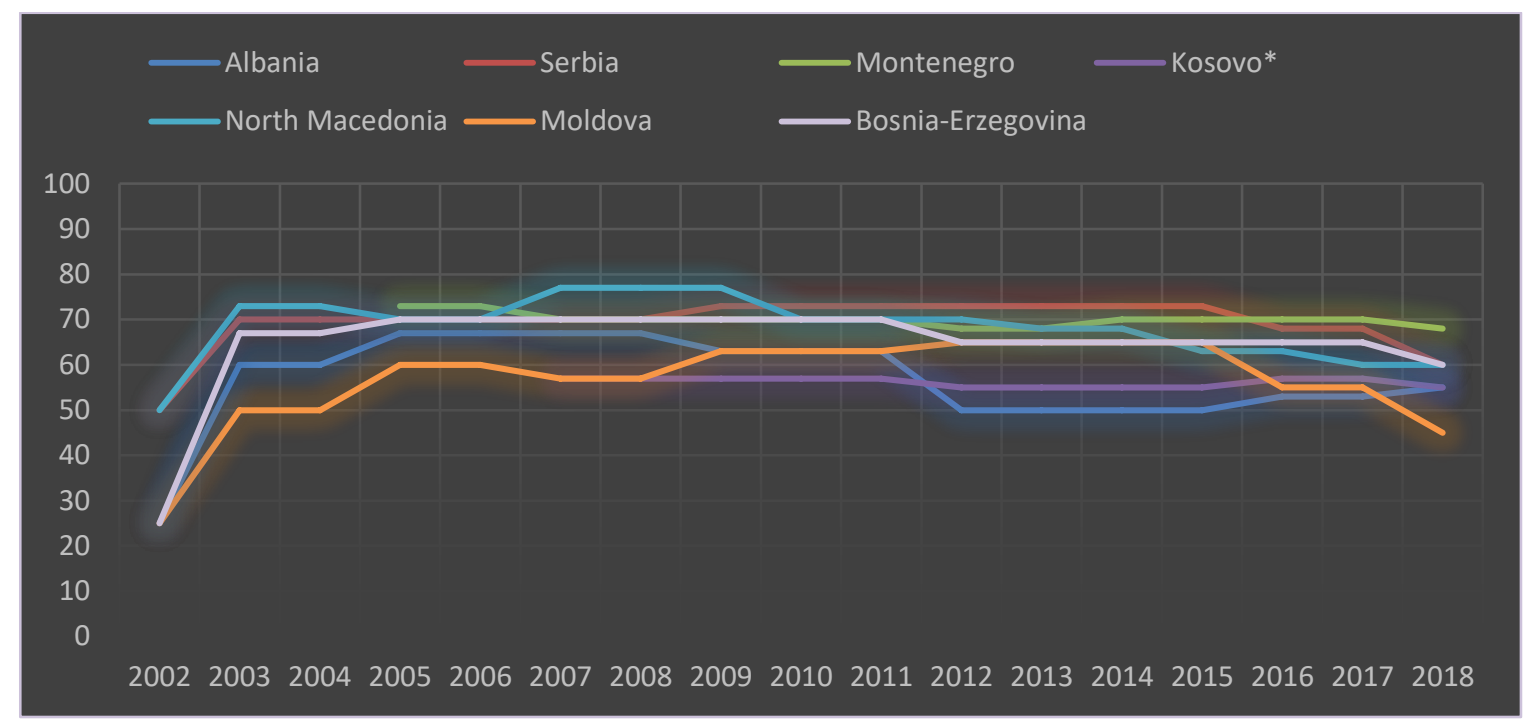

Source: WGI, 2020

Figure 14: Rule of Law

Last but not least, corruption plays also a significant role in domestic political environment since, among others, it weakens democracy and harms economic development by increasing inequality and poverty. According to Figure 15, corruption index takes prices from o to 100. Highly corrupted are close to 0 while very clean are close to 100 .

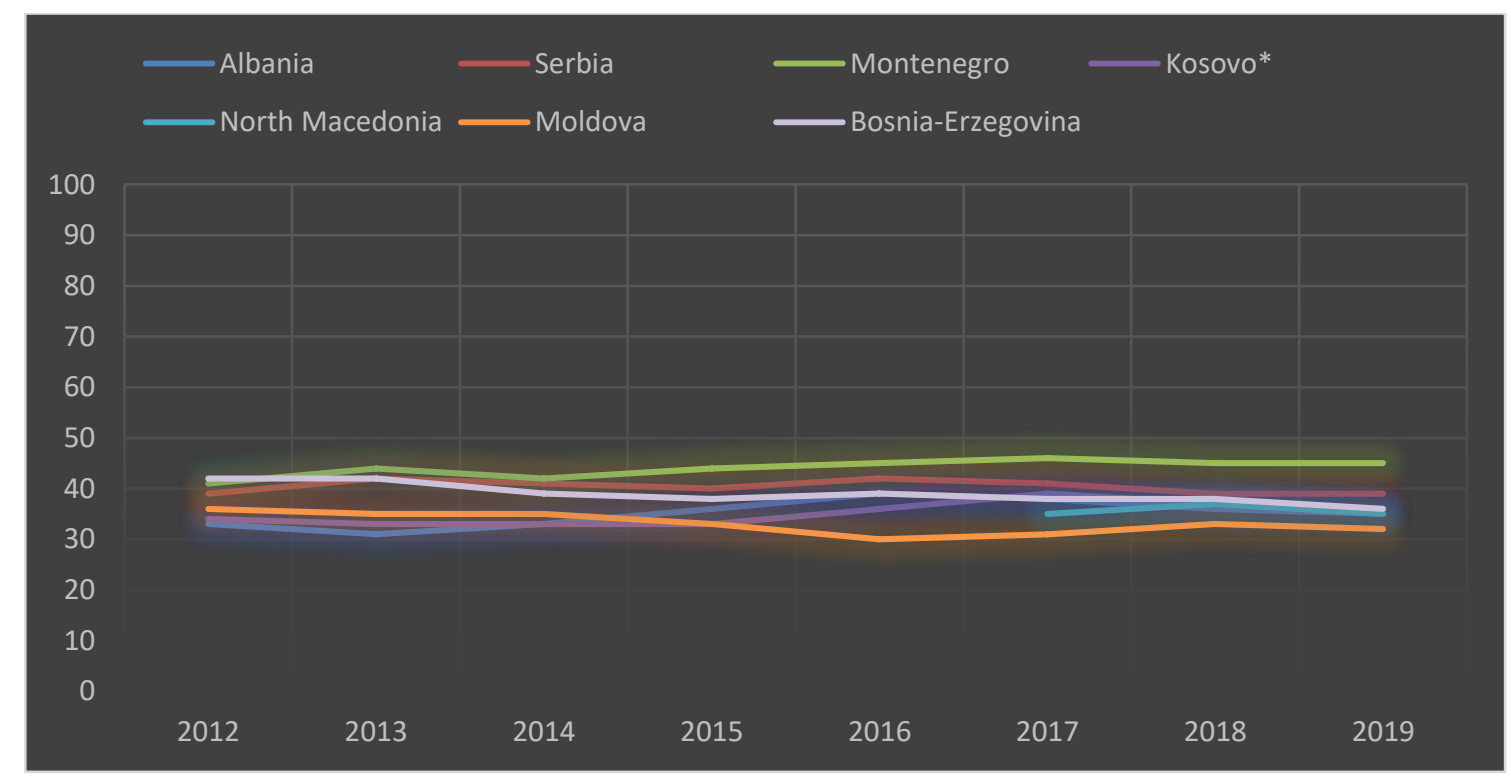

Source: Corruption Perception Index, 2020

Figure 15: Corruption

Regarding corruption among CEFTA's members, they are all below 50, meaning that they have high levels of corruption. In particular, Montenegro and Serbia are less corrupted than the others while Moldova, North Macedonia, Kosovo and Bosnia-Herzegovina seem to be the most corrupted from 2003 onwards.

\section{Conclusion}

The aim of the paper was to evaluate the impact of CEFTA on exports and economic growth and development of its members. Based on the theoretical context of Regional Trade Agreements, the assessment concerned quantitative analysis of intra-regional macroeconomic variables and development indexes along with domestic economic and political variables. The contradictory arguments in the literature regarding the effects of CEFTA on its members concerned those who argued that CEFTA'S impact on exports and economic growth and development of its members is positive and those who claimed that this impact is either very limited or no existent at all. This study, attempted to make an initial assessment about CEFTA's impact on its members' economic growth and development taking into consideration the wider economic and political environment. 
First, according to the literature, most of the scholars found that RTA's are positively correlated with economic growth and income. Since CEFTA's formation, there was not a significant change on growth rates however, GDP per capita increased. In addition, as far as trade is concerned, FTA's have substantial trade creation effects and increase bilateral and intra-regional volume. In the case of CEFTA, intra-regional trade seems to be neglected since all CEFTA members prefer trading with the EU. This does not mean that CEFTA's economies could be more competitive than the $\mathrm{EU}$, however, there are is no increase in intra-regional trade volume and when there is, this concerns only few of the partners. In addition, FDI were not examined due to lack of data.

Moreover, trade liberalization reduces income inequality. In the case of CEFTA, further to trade liberalization, indexes show that economic environment remains protected and state centric. Political instability, corruption and rule of low remain in low levels affecting at the same time negatively economic liberalization, as the theory predicts. On the other hand, income inequality is low despite the low levels of trade and economic liberalization while HDI is positively increasing.

Last but not least, there are mixed results that should further be examined. The fact that an FTA such as CEFTA seems that does not have any impact on GDP growth but at the same time GDP per capita and HDI are increasing, might show that there are other variables which affect these indexes. On the other hand, another paradox is that these positive developments happen in highly corrupted, state-centric and protectionist members of a Free Trade Agreement. Also, more attention should be given to the nature of a FTA, if its formation derives from political rather than economic motives, as well as the similarity of the domestic political and economic structures of its members. The latter might be a determinant on further integration within a RTA, if we consider EU's accession prerequisites.

\section{References}

Alcalá, F., \& Ciccone, A. 2004, “Trade and productivity”, The Quarterly journal of economics, 119, 2, pp.613-646.

Álvarez, I. C., Barbero, J., Rodríguez-Pose, A., \& Zofío, J. L., 2018 "Does institutional quality matter for trade? Institutional conditions in a sectoral trade framework", World Development, 103, pp.72-87.

Anderson, J. E., \& Yotov, Y. V., 2016, "Terms of trade and global efficiency effects of free trade agreements, 19902002", Journal of International Economics, 99, pp.279-298.

Ariyasajjakorn, D., Gander, J. P., Ratanakomut, S., \& Reynolds, S. E., 2009, “ASEAN FTA, distribution of income, and globalization", Journal of Asian Economics, 20, 3, pp.327-335.

Atif, R. M., Jadoon, A., Zaman, K., Ismail, A., \& Seemab, R., 2010, "Trade liberalization, financial development and economic growth: Evidence from Pakistan (1980-2009”, Journal of International Academic Research, 10,2, pp.30-37

Baccini, L., \& Dür, A. 2012, "The new regionalism and policy interdependence" British Journal of Political Science, 42,1, pp.57-79.

Badinger, H., \& Breuss, F., 2011, “The quantitative effects of European post-war economic integration” International handbook on the economics of integration: factor mobility, agriculture, environment and quantitative studies, 3, pp.285-315

Baier, S. L., \& Bergstrand, J. H., 2004, "Economic determinants of free trade agreements" Journal of international Economics, 64,1, pp.29-63.

Baier, S. L., \& Bergstrand, J. H., 2007, “Do free trade agreements actually increase members' international trade?” Journal of international Economics, 71,1, pp.72-95

Balassa, B., 1974, "Trade creation and trade diversion in the European Common Market: An appraisal of the evidence" The Manchester School, 42,2, pp.93-135.

Balding, C., 2011, "A re-examination of the relation between democracy and international trade" The Journal of International Trade $\&^{2}$ Economic Development, 20,5, pp.585-603.

Baldwin, R., 1993, “A domino theory of regionalism (working paper No. 4465). National bureau of economic research.

Baldwin, R. E., 1997, “The causes of regionalism” World Economy, 20,7, pp. 865-888.

Baldwin, R., \& Jaimovich, D., 2012, “Are free trade agreements contagious?”, Journal of international Economics, 88,1, pp.116.

Baltagi, B. H., Egger, P., \& Pfaffermayr, M., 2008, "Estimating regional trade agreement effects on FDI in an interdependent world”, Journal of Econometrics, 145,1-2, pp.194-208.

Bandyopadhyay, S., \& Roy, S., 2007, "Corruption and trade protection: evidence from panel data". Available at SSRN 988433.

Begović, S., 2011, "The effect of free trade agreements on bilateral trade flows: the case of CEFTA" Zagreb International Review of Economics \& Business, 14,2, pp.51-69.

Benacek, V., Lenihan, H., Andreosso-O'Callaghan, B., Michalíková, E., \& Kan, D., 2014 "Political risk, institutions and foreign direct investment: How do they relate in various European countries?” The World Economy, available at SSRN: https://ssrn.com/abstract=3181179

Ben-David, D., 1993 "Equalizing exchange: Trade liberalization and income convergence", The Quarterly Journal of Economics, 108 3, pp.653-679.

Berger, A., Busse, M., Nunnenkamp, P., \& Roy, M., 2013, "Do trade and investment agreements lead to more FDI? Accounting for key provisions inside the black box” International Economics and Economic Policy, 10, 2, pp.247-275. 
Blackburn, K., \& Forgues-Puccio, G. F., 2010 "Financial liberalization, bureaucratic corruption and economic development” Journal of International Money and Finance, 29,7, pp.1321-1339.

Borraz, F., Rossi, M., \& Ferres, D., 2012, "Distributive effects of regional trade agreements on the 'Small Trading Partners': mercosur and the case of uruguay and Paraguay" The Journal of Development Studies, 48, 12, pp.1828-1843

Brada, J. C., \& Méndez, J. A., 1988, "Exchange rate risk, exchange rate regime and the volume of international trade" Kyklos, 41,2, pp.263-280.

Bussmann, M., Scheuthle, H., \& Schneider, G., 2006, "Trade liberalization and political instability in developing countries" In Programming for Peace, Springer, Dordrecht, pp. 49-70.

Cai, K., 2010, The politics of economic regionalism: explaining regional economic integration in East Asia, Springer.

Capling, A., 2008 "Preferential trade agreements as instruments of foreign policy: an Australia-Japan free trade agreement and its implications for the Asia Pacific region" The Pacific Review, 21, 1, pp.27-43.

Carrere, C., 2006, "Revisiting the effects of regional trade agreements on trade flows with proper specification of the gravity model”, European Economic Review, 50, 2, pp.223-247.

Ćejvanović, F., Ivanković, M., Lasić, M., \& Vaško, Ž., 2014, "The impact of foreign trade in agricultural products of Bosnia and Herzegovina within the framework of CEFTA 2006” Economics of Agriculture, 61,4, pp.975-987.

Cherkaoui, M., Khellaf, A., \& Nihou, A., 2011, "The price effect of tariff liberalization in MOROCCO: Measuring the impact on household welfare" In Politics and economic development, Economic Research Forum, available at https://www.researchgate.net/profile/Ayache_Khellaf/publication/331895570_THE_PRICE_EFFECT_OF_TARI FF_LIBERALIZATION_IN_MOROCCO_MEASURING_THE_IMPACT_ON_HOUSEHOLD_WELFARE/links /5c92262192851cfoae89f769/THE-PRICE-EFFECT-OF-TARIFF-LIBERALLIZATION-IN-MOROCCOMEASURING-THE-IMPACT-ON-HOUSEHOLD-WELFARE.pdf

Clairzier, P., 2011, "Paths to Development through Trade: EU-Led Trade Liberalization vs South-South Cooperation”, Socialism and Democracy, 25,2, pp.64-80.

Clausing, K. A., 2001, "Trade creation and trade diversion in the Canada-United States free trade agreement" Canadian Journal of Economics/Revue canadienne d'économique, 34,3, pp.677-696.

Cooper, C. A., \& Massell, B. F., 1965, “A new look at customs union theory” The economic journal, 75, 300, pp. 742-747.

da Conceição-Heldt, E., 2011, Negotiating trade liberalization at the WTO: Domestic politics and bargaining dynamics. Springer.

Dai, M., Yotov, Y. V., \& Zylkin, T., 2014, "On the trade-diversion effects of free trade agreements" Economics Letters, 122,2, pp.321-325.

Dangerfield, M., 2001, "Subregional cooperation in central and Eastern Europe: Support or substitute for the 'return to Europe'?”, Perspectives on European Politics and Society, 2,1, pp.55-77.

Dangerfield, M., 2004, "CEFTA: Between the CMEA and the European Union”, Journal of European Integration, 26,3, pp.309-338.

De Groot, H. L., Linders, G. J., Rietveld, P., \& Subramanian, U., 2004, “The institutional determinants of bilateral trade patterns" Kyklos, 57,1, pp.103-123.

Doces, J. A., \& Magee, C. S., 2015, “Trade and democracy: A factor-based approach” International Interactions, 41,2, pp.407425 .

Dollar, D.,1992, "Outward-oriented developing economies really do grow more rapidly: evidence from 95 LDCs, 19761985 ” Economic development and cultural change, 40,3, pp.523-544.

Dollar, D., \& Kraay, A., 2004, “Trade, growth, and poverty”, The Economic Journal, 114,493, pp.22-49.

Duong, M., Holmes, M. J., Strutt, A., \& Lim, S., 2019, "Effects of Trade Agreements and Foreign Direct Investment on Trade: Evidence from Vietnam” International Journal of Economics and Financial Issues, 9,3, pp.116-126.

Dutt, P., 2009, "Trade protection and bureaucratic corruption: an empirical investigation”, Canadian Journal of Economics/Revue canadienne d'économique, 42,1, pp.155-183.

Frankel, J. A., \& Romer, D. H.,1999, “Does trade cause growth?”, American economic review, 89,3, pp.379-399.

Freund, C., \& Bolaky, B., 2008, “Trade, regulations, and income”, Journal of development economics, 87,2, pp.309-321.

Frye, T., \& Mansfield, E. D., 2004, "Timing is everything: Elections and trade liberalization in the postcommunist world”, Comparative Political Studies, 37,4, pp.371-398.

Fukao, K., Okubo, T., \& Stern, R. M., 2003, “An econometric analysis of trade diversion under NAFTA”, The North American Journal of Economics and Finance, 14,1, pp.3-24.

CEFTA, 2020(a), "Support to Facilitation of Trade between CEFTA Parties", https://cefta.int/trade-facilitation, (May 2020)

CEFTA, 2020(b), “Trade in goods”, https://statistics.cefta.int/goods (May 2020)

CEFTA, 2020(c), "Intra-regional FDI inflows/outflows", https://statistics.cefta.int/indicator/14, (May 2020).

Corruption Perception Index, 2020, https://www.transparency.org/en/cpi/1995/results/alb, (May 2020).

Ghosh, S., \& Yamarik, S., 2004, "Are regional trading arrangements trade creating?: An application of extreme bounds analysis”, Journal of International Economics, 63,2, pp.369-395.

Gibson, P., Wainio, J., Whitley, D., \& Bohman, M., 2003, "Profiles of tariffs in global agricultural markets”, Economic Research Service, U.S. Department of Agriculture. Agricultural Economic Report No. 796, available at https://www.gtap.agecon.purdue.edu/resources/download/1269.pdf

Gilpin, R., 1981, War and Change in World Politics. Cambridge University Press, New York, USA.

Gjonbalaj, M., Musliu, A., \& Ahmeti, S., 2011, "Evaluating impact of CEFTA agreement for Kosovo", Anadolu International Conference in Economics II, June 15-17, 201 1, Eskişehir, Turkey 
Gnangnon, S. K., 2019, "Does multilateral trade liberalization help reduce poverty in developing countries”, Oxford Development Studies, 47,4, pp.435-451.

Goldstein, J., \& Martin, L. L., 2000, "Legalization, trade liberalization, and domestic politics: a cautionary note”, International organization, 54,3, pp.603-632.

Hadjiyiannis, C., Heracleous, M. S., \& Tabakis, C., 2016, "Regionalism and conflict: Peace creation and peace diversion”, Journal of International Economics, 102, pp.141-159.

Hamid, Z., \& Amin, R. M., 2013, “Trade and human development in OIC countries: A panel data analysis”. Islamic Economic Studies, 130,905, pp.1-15.

HDI, 2020, "Human Development Index" http://hdr.undp.org/en/countries, (May 2020)

Higgott, R., 2004, “US foreign policy and the 'securitization' of economic globalization”, International Politics, 41,2, pp. $147-175$.

Hur, J., \& Park, C., 2012, “Do free trade agreements increase economic growth of the member countries?”, World development, 40,7, pp.1283-1294.

Index of Economic Freedom, 2020, https://www.heritage.org/index/?version=482 (May 2020)

Ingco, M. D., 1995, “Agricultural liberalization in the Uruguay Round”, Finance and Development, 32,3, pp.43.

Jalles, J. T., 2012, "Openness, regional trade agreements and growth: evidence from Asia”, Asian Economic Journal, 26,1, pp.63-85.

Jang, Y. J., 2011, “The impact of bilateral free trade agreements on bilateral foreign direct investment among developed countries", The World Economy, 34,9, pp.1628-1651.

Jaumotte, M. F., 2004, "Foreign direct investment and regional trade agreements: The market size effect revisited (No. 4206)". IMF Working Paper No. 04/206, available at https://ssrn.com/abstract $=879031$

Jawaid, S. T., \& Waheed, A., 2017, "Contribution of international trade in human development of Pakistan", Global Business Review, 18,5, pp.1155-1177.

Kanazawa, R., \& Kang, M., 2019, "The Impact of ASEAN-Korea Free Trade Agreement on Foreign Direct Investment", Korea and the World Economy, 20,1, pp.43-63.

Kar, M., Peker, O., \& Kaplan, M., 2008, "Trade liberalization, financial development and economic growth in the long term: The case of Turkey”, South East European Journal of Economics and Business, 3,2, pp.25-38.

Karras, G., 2003, “Trade Openness and Economic Growth Can We Estimate the Precise Effect?”, Applied Econometrics and International Development, 3,1, available at https://ssrn.com/abstract $=1225622$.

Kelton, M., 2008, "US economic statecraft in East Asia", International relations of the Asia-Pacific, 8,2, pp. 149-174.

Krueger, A. O., 1999, “Trade creation and trade diversion under NAFTA (No. w7429)”, National Bureau of Economic Research, available at https://www.nber.org/papers/w7429.

Langbein, J., 2016, “(Dis-) integrating Ukraine? Domestic oligarchs, Russia, the EU, and the politics of economic integration”, Eurasian Geography and Economics, 57,1, pp.19-42.

Langhelle, O. (Ed.), 2013, International trade negotiations and domestic politics: The Intermestic politics of trade liberalization. Routledge.

Lee, Y., \& Azfar, O., 2008, "Corruption and trade regulations: an instrumental variable approach", Applied Economics Letters, 15,3, pp.231-234.

Levchenko, A. A., 2007, "Institutional quality and international trade”, The Review of Economic Studies, 74,3, pp.791-819.

Li, Q., Scollay, R., \& Maani, S., 2016, "Effects on China and ASEAN of the ASEAN-China FTA: The FDI perspective", Journal of Asian Economics, 44, pp.1-19.

Liu, X., 2016, “Trade agreements and economic growth”, Southern Economic Journal, 82,4, pp.1374-1401.

Liu, X., \& Ornelas, E., 2014, "Free trade agreements and the consolidation of democracy", American Economic Journal: Macroeconomics, 6,2, pp.29-70.

Lohmann, S., \& O'halloran, S., 1994, "Divided government and US trade policy: theory and evidence", International organization, 48,4, pp.595-632.

Madeira, M. A., 2016, "New trade, new politics: intra-industry trade and domestic political coalitions", Review of International Political Economy, 23,4, pp.677-711.

Martin, P., Mayer, T., \& Thoenig, M., 2012, “The geography of conflicts and regional trade agreements”, American Economic Journal: Macroeconomics, 4,4, pp.1-35.

Mastanduno, M., 1998, "Economics and Security in Statecraft and Scholarship" International Organization, 52,4, pp. 825854

Mattoo, A., Mulabdic, A., \& Ruta, M., 2017, "Trade creation and trade diversion in deep agreements", The World Bank, available at https://elibrary.worldbank.org/doi/abs/10.1596/1813-9450-8206.

McKibben, H. E., \& Taylor, T. W., 2020, “Trade balance and policy complexity: explaining political elites' focus on international trade at the domestic level”, International Interactions, 46, 1, pp.28-50.

Milner, H. V., \& Kubota, K., 2005, "Why the move to free trade? Democracy and trade policy in the developing countries”, International organization, 59,1, pp.107-143.

Milner, H. V., \& Rosendorff, B. P., 1996, "Trade negotiations, information and domestic politics: The role of domestic groups", Economics \& Politics, 8,2, pp.145-189.

Milner, H. V., \& Rosendorff, B. P., 1997, "Democratic politics and international trade negotiations: Elections and divided government as constraints on trade liberalization”, Journal of Conflict resolution, 41,1, pp.117-146.

Milošević, A., \& Hrnjaz, M., 2018, "Exploring Serbia-Kosovo Trade Relations: Achieving Peace through Trade Interdependence?”. Ethnopolitics, 17,1, pp.95-112. 
Narayan, S., \& Bui, N. M. T., 2019, "Does Corruption in Exporter and Importer Country Influence International Trade?", Emerging Markets Finance and Trade, pp.1-20

Nicita, A., 2009, "The price effect of tariff liberalization: Measuring the impact on household welfare", Journal of Development Economics, 89,1, pp.19-27.

Nunn, N., \& Trefler, D., 2014, "Domestic institutions as a source of comparative advantage", in Handbook of international economics, Elsevier, pp. 263-315.

Onakoya, A., Johnson, B., \& Ogundajo, G., 2019, "Poverty and trade liberalization: empirical evidence from 21 African countries”, Economic research-Ekonomska istraživanja, 32,1, pp.635-656.

Petersmann, E. U., 2015, "Transformative transatlantic free trade agreements without rights and remedies of citizens?", Journal of international economic law, 18,3, pp.579-607.

Petreski, M., 2013, “Southeastern European trade analysis: A role for endogenous CEFTA-2006?", Emerging Markets Finance and Trade, 49,5, pp.26-44.

Petreski, M., 2018, "Has CEFTA Increased Members' Mutual Trade? Evidence with an Enlarged Set of Plausibly Exogenous Instruments", Finance a Uver, 68,3, pp.293-316.

Porto, G., 2010, "International market access and poverty in Argentina”, Review of International Economics, 18,2, pp.396407.

Ramanayake, S. S., \& Lee, K., 2015, "Does openness lead to sustained economic growth? Export growth versus other variables as determinants of economic growth”, Journal of the Asia Pacific Economy, 20,3, pp.345-368.

Ramanzini Júnior, H., \& Luciano, B. T., 2020, "Regionalism in the Global South: Mercosur and ECOWAS in trade and democracy protection”, Third World Quarterly, pp.1-20.

Ravenhill J., 2017, Global Political Economy. Oxford University Press, Oxford, United Kingdom

Reed, R., Lira, C., Byung-Ki, L., \& Lee, J., 2016, "Free trade agreements and foreign direct investment: The role of endogeneity and dynamics”, Southern Economic Journal, 83,1, pp.176-201.

Richardson, M., 1993, "Endogenous protection and trade diversion", Journal of International Economics, 34,3-4, pp.309-324.

Rodriguez, F., \& Rodrik, D., 2000, "Trade policy and economic growth: a skeptic's guide to the cross-national evidence", NBER macroeconomics annual, 15, pp.261-325.

Romalis, J., 2007, "NAFTA's and CUSFTA's Impact on International Trade”, The review of Economics and Statistics, 89,3, pp.416-435.

Sarker, R., \& Jayasinghe, S., 2007, "Regional trade agreements and trade in agri-food products: evidence for the European Union from gravity modeling using disaggregated data", Agricultural Economics, 37,1, pp.93-104.

Schejtman, A., Berdegué, J. A., \& Florez, V., 2009, “Trade and poverty in Latin America”, Inter-American Development Bank, Washington, DC, pp.249-322.

Siddiqui, K., 2015, “Trade liberalization and economic development: A critical review”, International Journal of Political Economy, 44,3, pp.228-247.

Solís, M., 2010, "Can FTAs deliver market liberalization in Japan? A study on domestic political determinants", Review of International Political Economy, 17,2, pp.209-237.

Soloaga, I., \& Wintersb, L. A., 2001, "Regionalism in the nineties: What effect on trade?", The North American Journal of Economics and Finance, 12,1, pp.1-29.

Sudsawasd, S., Charoensedtasin, T., \& Pholphirul, P., 2020, "Does international trade enable a country to achieve Sustainable Development Goals? Empirical findings from two research methodologies", International Journal of Sustainable Development \& World Ecology, 27,5, pp.405-418.

Sun, L., \& Reed, M. R., 2010, "Impacts of free trade agreements on agricultural trade creation and trade diversion”, American Journal of Agricultural Economics, 92,5, pp.1351-1363.

Tavares, S., 2005, "Does Rapid Liberalization Increase Corruption?”, In European Public Choice Society conference, University of Durham.

Tavares, S. C., 2007, “Do rapid political and trade liberalizations increase corruption?", European Journal of Political Economy, 23,4, pp.1053-1076.

Thangavelu, S. M., \& Narjoko, D., 2014, "Human capital, FTAs and foreign direct investment flows into ASEAN", Journal of Asian Economics, 35, pp.65-76.

Tumwebaze, H. K., \& Ijjo, A. T., 2015, "Regional economic integration and economic growth in the COMESA region, 1980-2010”, African Development Review, 27,1, pp. 67-77.

UNDP, 2020, "Income Inequality, GINI Coefficient", http://hdr.undp.org/en/indicators/67 106, (May 2020)

Vamvakidis, A., 1999, "Regional trade agreements or broad liberalization: which path leads to faster growth?”, IMF Staff papers, 46,1, pp.42-68.

Vicard, V., 2012, "Trade, conflict, and political integration: Explaining the heterogeneity of regional trade agreements", European Economic Review, 56,1, pp.54-71.

Wacziarg, R., \& Welch, K. H., 2008, “Trade liberalization and growth: New evidence”, The World Bank Economic Review, 22,2, pp.187-231.

Wesley, M., 2008, "The strategic effects of preferential trade agreements", Australian Journal of International Affairs, 62,2, pp. 214-228.

WGI, 2020, "World Governance Index" available at https://info.worldbank.org/governance/wgi/Home/Reports, (May 2020)

Winters, L. A., \& Martuscelli, A., 2014, “Trade liberalization and poverty: What have we learned in a decade?”, Annual Review of Resource Economics, 6,1, pp.493-512. 
Winters, L. A., McCulloch, N., \& McKay, A., 2004, “Trade liberalization and poverty: the evidence so far", Journal of economic literature, 42,1, pp.72-115.

World Bank 2020(a), "GDP growth (annual \%)", https://data.worldbank.org/indicator/NY.GDP.MKTP.KD.ZG, (May 2020)

World Bank 2020(b), “GDP per capita, PPP”, https://data.worldbank.org/indicator/NY.GDP.PCAP.PP.CD, (May 2020)

WTO, 2020, "Central European Free Trade Agreement (CEFTA) 2006", http://rtais.wto.org/UI/PublicShowRTAIDCard.aspx?rtaid=4, (May 2020)

Yang, S., \& Martinez-Zarzoso, I., 2014, "A panel data analysis of trade creation and trade diversion effects: The case of ASEAN-China Free Trade Area”, China Economic Review, 29, pp.138-151.

Yeyati, E. L., Stein, E. H., \& Daude, C, 2003, "Regional Integration and the Location of FDI", ECONSTOR (Working paper No. 492), available at https://www.econstor.eu/bitstream/10419/87947/1/idb-wp_492.pdf.

Yu, S., Beugelsdijk, S., \& de Haan, J., 2015, "Trade, trust and the rule of law", European Journal of Political Economy, 37, pp.102-115.

This is an Open Access article distributed under the terms of the Creative Commons Attribution Licence

(c) (i) 